\title{
Anthrapyrazole Antineoplastic Antibiotic
}

National Cancer Institute

\section{Source}

National Cancer Institute. Anthrapyrazole Antineoplastic Antibiotic. NCI Thesaurus. Code C2107.

A class of antibiotics related to the anthracycline antineoplastic antibiotics. The anthrapyrazole antibiotics intercalate into DNA and interact with topoisomerase II, thereby inhibiting DNA replication and repair and RNA and protein synthesis. These agents may also block cell cycle division. In the presence of electron donors, some anthrapyrazole antibiotics cause sing le-strand breaks in DNA via photosensitization by visible light. These agents are less cardiotoxic than doxorubicin. ( $\mathrm{NClO4)}$ 